This PDF is a selection from an out-of-print volume from the National Bureau of Economic Research

Volume Title: Inflation, Tax Rules, and Capital Formation

Volume Author/Editor: Martin Feldstein

Volume Publisher: University of Chicago Press

Volume ISBN: 0-226-24085-1

Volume URL: http://www.nber.org/books/feld83-1

Publication Date: 1983

Chapter Title: Inflation and the Taxation of Capital Income in the Corporate Sector

Chapter Author: Martin Feldstein, Lawrence Summers

Chapter URL: http://www.nber.org/chapters/c11333

Chapter pages in book: (p. $116-152)$ 

in the Corporate Sector

With Lawrence Summers

This paper presents a detailed examination of the effect of inflation on the taxation of capital used in the nonfinancial corporate sector of the U.S. economy. Our analysis shows that, with current tax laws, inflation substantially increases the effective tax rate on capital income in the corporate sector. The principal reason for this is that the historic cost method of depreciation causes a major overstatement of taxable profits, i.e., historic cost depreciation results in a large increase in the level of real taxable profits at any level of real economic profits. Current methods of inventory accounting add further to this overstatement of profits for $\operatorname{tax}$ purposes.

According to our most comprehensive calculation, the effect of inflation with existing tax laws was to raise the 1977 tax burden on corporate sector capital income by more than $\$ 32$ billion. This extra tax burden equivalent to 69 percent of the real after-tax capital income of the nonfinancial corporate sector, including retained earnings, dividends, and real interest receipts of the corporations' creditors. Since our calculations show that the total tax burden on this corporate capital income was $\$ 92$ billion, the extra tax burden raised the tax by more than 54 percent. The total effective tax rate on corporate sector capital income in 1977 was 66 percent; without the extra tax caused by inflation, the effective tax rate would have been only 41 percent.

In contrast to previous studies of the relation between inflation and corporate tax burdens, we consider not only the tax paid by the corpora-

Reprinted by permission from National Tax Journal 32 (December 1979): 445-70.

This paper is part of the NBER study of capital formation. The authors are grateful for comments on earlier drafts by particlpants in a meeting of the NBER research group on taxation and several anonymous referees. James Poterba, Stephanle Seligman, and Daniel Smith provided valuable assistance. 
tions themselves but also the tax paid by the individuals and institutions that supply capital to the corporate sector. ${ }^{1}$ This is particularly important for a correct treatment of corporate debt. Inflation implies that the nominal interest payments that corporations deduct in calculating taxable profits exceed the real cost of borrowed funds; in itself, this tends to understate real profits and to lower the effective tax rate. ${ }^{2}$ However, the individuals and institutions that lend to the corporations are taxed on the overstated nominal interest income. ${ }^{3}$ Our calculations show that the excess tax paid by the lenders is slightly greater than the tax saving of the corporate borrowers. Since the difference between the relevant tax rate for borrowers and lenders is quite small, the mismeasurement of interest income (or, equivalently, the real gains and losses on net corporate debt) can be ignored without seriously distorting the evaluation of the overall effect of inflation on the taxation of corporate sector capital.

In addition to our analysis of the nonfinancial corporate sector as a whole, the present study makes use of an important new source of data for individual firms on the values of both replacement cost depreciation and depreciation based on historic costs. Beginning with the year 1976, the Securities and Exchange Commission has required large corporations to provide information on replacement cost depreciation and inventory profits as part of their annual form $10-\mathrm{K}$ reports. We use these data together with other information on the financial and real performance of 327 individual manufacturing firms in order to examine how inflation has raised the effective tax rates on different industries.

In the first section of this study, we ignore the mismeasurement of interest expenses and income in order to focus on the additional taxation caused by historic cost depreciation and by existing inventory accounting methods. Section 8.2 then shows that the corporate tax savings that result from overstating real interest expenses are slightly more than balanced by the greater tax burdens that the mismeasurement of interest income imposes on the individuals and institutions that directly and indirectly supply debt capital to the corporate sector. The total increase in tax liabilities on corporate source income due to inflation is then estimated in section 8.3. Section 8.4 describes inflation's impact on effective tax rates. The fifth section then uses the data on individual firms to calculate the

1. Studies that have focused on inflation's effect on corporate taxes include Davidson and Weil (1977), Lovell (1978), Shoven and Bulow (1976) and Tideman and Tucker (1977). The Importance of looking through the corporation to examine the return to suppllers of debt and equity capital is stressed in Feldstein (1976; chap. 3 above), Feldstein, Green, and Sheshinski (1978; chap. 4 above), and Feldstein and Summers (1978; chap. 9 below).

2. Allowing the deduction of nominal interest payments that exceed real interest payments is equivalent to ignoring the real gains that accrue to corporations as inflation reduces the real value of ourstanding corporate debt. In thls context, debt should of course be regarded as gross debt minus nominal assets.

3. The extent of this taxation differs substantlally among the different classes of lenders. 
extent of additional taxation in each of the 20 different manufacturing industries. There is a brief concluding section that discusses the implications of these higher effective tax rates for capital formation and economic performance. ${ }^{4}$

\subsection{Depreciation Rules, Inventory Accounting and Corporate Tax Payments}

A desirable taxation criterion is that real tax payments should not be affected by changes in the overall price level which do not alter real income or wealth. Our tax system violates this standard in its treatment of corporate profits. When the price level rises and firms' real profits remain constant, their real tax payments rise both because of historical cost depreciation and FIFO inventory accounting. The real cost of the depreciating of a firm's capital stock is the replacement cost of the obsolescent capital. Yet for tax purposes firms are only permitted to deduct depreciation based on the original purchase price. In inflationary periods, this may be much less than the replacement cost. Similarly, the cost of depleting inventories is the replacement cost of the goods, not their original acquisition cost. Firms which use FIFO inventory cost deduct only the acquisition cost, giving rise to phantom inventory profits.

In this section, we discuss our estimates of how much existing depreciation and inventory rules raise corporate taxes in our inflationary economy. We ignore the role of debt and limit our attention to the tax burdens at the level of the corporation; this restriction is dropped in the subsequent sections where, as we noted in the introduction, we show that explicit recognition of debt has little effect on the total additional taxation of all the capital used in the corporate sector because of the offsetting effects of inflation on the taxation of borrowers and lenders. We begin this section by examining the experience for 1977, the most recent year for which all the required information is available. We then discuss the trends in inflation's effects on the taxation of corporate source income over the period since $1954 .^{5}$

4. The analysis relates only to nonfinancial corporations even when the text refers only to corporations. Throughout the study we make no attempt to assess the extent to which the initial tax burdens are shifted to other capital or to labor by changes in the allocation of capital or in the financial decisions of households and firms. We also ignore state and local taxes and, to that extent, understate total tax burdens.

5. It is important to recall that firms may use LIFO inventory accounting for tax purposes only if they also use LIFO in the "book" accounting statements that they report to shareholders and creditors. Although the extra taxes that result from FIFO accounting are in a sense voluntary, managements presumably pay these taxes because they believe that the re would be greater costs of some other kind if they used LIFO and reported lower profits and assets. As long as firms do pay the higher taxes based on FIFO accounts, these taxes do affect investment and savings decisions. 


\subsubsection{The Experience of 1977}

Before looking in detail at the data for 1977 , we can summarize briefly the impact of inflation on the taxes paid by nonfinancial corporations in 1977. The cumulative effect of inflation reduced the depreciation allowed on existing plant and equipment by $\$ 39.7$ billion in 1977 . This raised corporate tax payments by $\$ 19$ billion, or nearly one-third of the $\$ 59$ billion of corporate tax liabilities for 1977 . An additional $\$ 7$ billion in taxes were paid on artificial inventory profits. Thus, inflation raised corporate taxes from $\$ 33$ billion to $\$ 59$ billion, an increase of 79 percent. Stating this in a different way, the additional corporate tax caused by inflation accounts for 57 percent of the $\$ 59$ billion of corporate tax liabilities in 1977.

We can now examine the specific data used to calculate these additional tax burdens. The official national income account estimate of the 1977 real profits of nonfinancial corporations was $\$ 113.9$ billion. ${ }^{6}$ Taxable profits for those corporations were $\$ 143.5$ billion in the same year. The $\$ 30$ billion difference between these two profit figures is the sum of the inventory valuation adjustment and the capital consumption adjustment. The inventory valuation adjustment (IVA) of $\$ 14.8$ billion implies that inflation added $\$ 14.8$ billion of false inventory profits to taxable income. The capital consumption adjustment (CCA) of $\$ 14.7$ billion $^{7}$ actually reflects two countervailing differences between real straight-line depreciation and the depreciation allowed for tax purposes: the accelerated depreciation rules made tax-deductible depreciation exceed straight-line depreciation by $\$ 25.0$ billion while inflation reduced the value of tax deductible depreciation and raised taxable profits by $\$ 39.7$ billion. We shall refer to the two components of the CCA as the "acceleration component" (CCA-A) and the "inflation component" (CCA-I). Thus historic cost depreciation plus false inventory profits together added $\$ 54.5$ billion to taxable profits. With a 48 percent statutory marginal tax rate, inflation caused a $\$ 26$ billion increase in corporate tax payments.

In calculating the additional corporate tax payments we have implicitly assumed that accelerated depreciation and the investment tax credit were enacted to stimulate investment and not as an offset to inflation. It is clear that these features were enacted long before adjusting taxable income for

6. Survey of Current Business, November 1978. For earlier years, we use the Survey of Current Business, March 1976, pages 53-57, and updates in the Survey of Current Business. Depreciation is based on straight-line depreciation at 85 percent of the Bulletin $F$ lives with depreciation calculated at replacement cost.

7. While the CCA is the only available estimate of the appropriate adjustment of depreciation allowances, there are serious problems with its construction. It is based on estimates of "capacity disappearance" rather than as a "value reduction" standard; the two are only exactly equivalent in the case of exponential depreciation. The underlying data on asset lives are often old and may as a result be incorrect. 
inflation was a serious issue. Accelerated depreciation was introduced to the tax law in 1954 (a year in which the CPI actually fell) because of a conviction that tax depreciation lives were too long. Extensions of accelerated depreciation in subsequent years appear to have been motivated by a desire to stimulate investment rather than as an offset to inflation. As Stanley Surrey noted in connection with the 1971 acceleration provisions that created the asset depreciation range (ADR) system. "The new Asset Depreciation Range system was urged by the Treasury and adopted by the Congress in 1971 not as a device needed to measure real net income ... (but) as an incentive for the purchases of new machinery and equipment" (Surrey, 1973, p. 32). Similarly the investment tax credit was introduced as a countercyclical measure to stimulate demand in 1962, a year in which the CPI rose only 1.2 percent.

Although the tax credits and accelerated depreciation that were legislated before the recent inflation can clearly be regarded as investment incentives rather than offsets to inflation, it might be argued that the changes made in the Tax Reduction Act of 1975 (and in subsequent legislation) were intended at least partly as an offset to the inflationary distortions of the tax liabilities. It is worth emphasizing therefore that these tax changes have done relatively little to reduce corporate taxes. The accelerated depreciation component of the capital consumption adjustment rose from $\$ 20.4$ billion in 1975 to $\$ 25$ billion in 1977 , an increase proportional to the nominal level of fixed investment in the nonfinancial corporate sector. The increase in the amount of the investment tax credit between 1975 and 1977 due to the liberalization enacted in $1975^{8}$ cannot be measured precisely but a reasonably accurate "upperbound" estimate can be made. If the 3 percent increase in the Investment Tax Credit rate applied to all equipment investment in 1977, the additional tax credit for nonfinancial corporations would have been only $\$ 3.4$ billion. This is clearly an overestimate of the additional investment tax credit because various limitations prevent all corporations from using the full 10 percent credit and because the rate is less than 10 percent on certain types of equipment. Furthermore, the 1975 liberalization of the I.T.C. can be ascribed at least as plausibly to antirecession policy as to a desire to offset inflation's impact on taxable profits.

\subsubsection{The Period Since 1954}

It is useful now to see the growing impact of inflation on tax liabilities by examining the evolution of taxable income and taxes since $1954 .{ }^{9}$ This

8. The Tax Reduction Act of 1975 raised the investment tax credit from 7 percent to 10 percent and liberalized the accelerated depreciation rules.

9. We begin with 1954 to avoid the complexities of the excess profits taxes that were levied during the Korean War. The Internal Revenue Code of 1954 represented a major overhaul of the tax law that, with amendments, continues to provide the framework for current tax legislation. 
analysis shows that, although inflation has caused some increase in corporate taxes for the past two decades, the period since 1970 has seen dramatically greater tax increases induced by inflation.

Table 8.1 presents annual information on the distortion of taxable profits caused by historic cost depreciation (CCA-I) and by artificial inventory accounting profits (IVA), the additional tax due to each of these, and the proportion of actual taxes that are accounted for by these extra taxes.

Consider first the reduced depreciation for tax purposes caused by historic cost accounting. Column 2 shows that this reduction in depreciation (CCA-I) remained less than $\$ 10$ billion a year until 1970 but reached $\$ 39.7$ billion in 1977 . The 1977 level is nearly double the 1974 level and nearly eight times the level of 1967 . This is reflected in the corresponding additional taxes shown in column 5 . While the additional tax due to historic cost depreciation varied between $\$ 2$ billion and $\$ 3$ billion a year until 1967 , it has doubled every three years since then: the additional taxes rose from $\$ 2.4$ billion in 1967 to $\$ 4.8$ billion in $1970, \$ 10.3$ billion in 1974 , and $\$ 19.1$ billion in 1977 . While the extra tax caused by historic cost depreciation accounted for 9 percent of actual corporate taxes in 1967 (see column 8), it accounted for 32 percent of the taxes paid in 1977.

The artificial inventory profits also remained very small until 1967 , never reaching $\$ 3$ billion (column 3 ). More recently, however, inventory profits have exceeded $\$ 10$ billion a year and the resulting excess profits have accounted for more than 10 percent of actual taxes paid.

Column 10 summarizes the overall effect of both sources of increased taxation. Until 1967, the extra tax caused by inflation accounted for 10 percent to 20 percent of the corporate taxes actually paid. This implies that the excess tax raised the tax that would otherwise have been paid by up to 25 percent. During the most recent five years, however, the excess tax accounted for an average of 50 percent of the corporate taxes actually paid. This implies that corporate taxes were twice as great as they would have been if replacement cost depreciation was permitted and artificial inventory profits were not taxed.

It is important to recognize that these distortions will continue to grow even if the rate of inflation does not accelerate any further. The understatement of an asset's depreciation allowance depends on the increase in the price level since it was purchased. Hence the understatement of depreciation will rise until inflation has lasted as long as the oldest asset which is still being depreciated. The accounting conventions used in our tax system make taxes very sensitive to the rates of inflation that we have recently experienced. The substantial additional tax burden caused by inflation will continue to grow unless either the tax law or the rate of inflation changes significantly. 


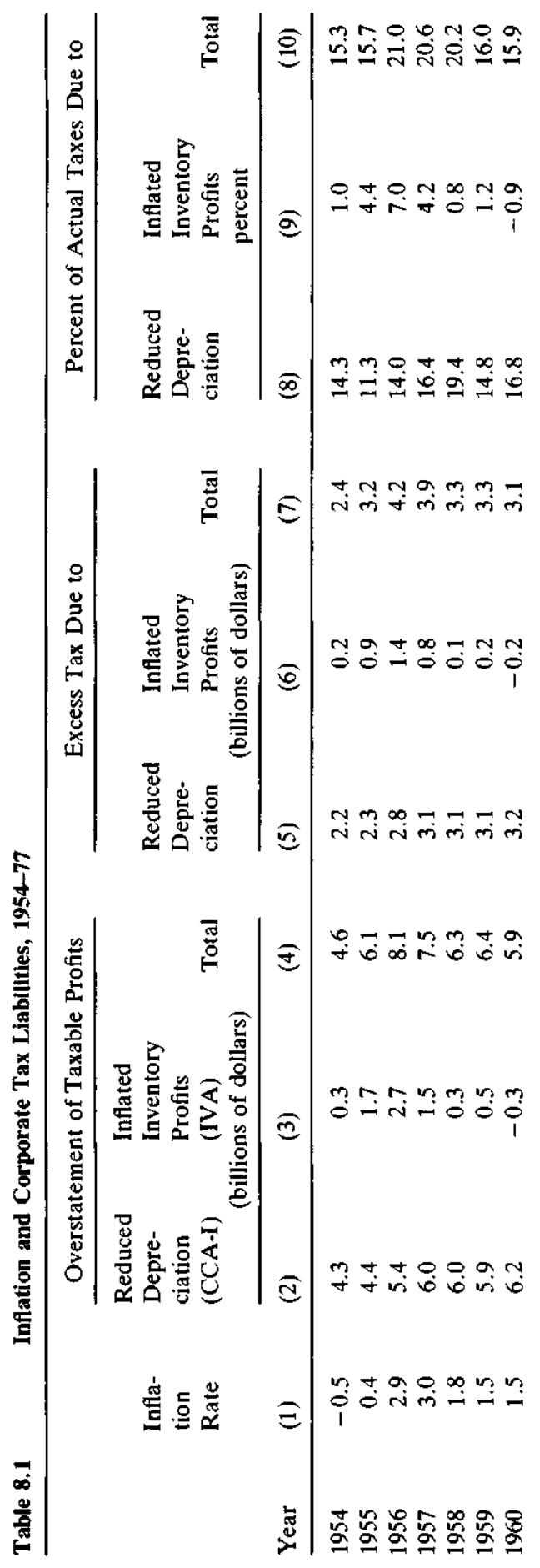




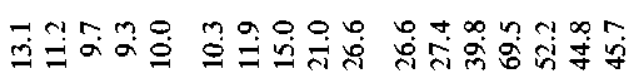

m+m

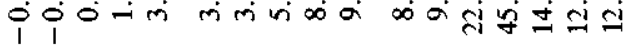

to पूं

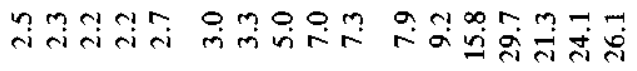

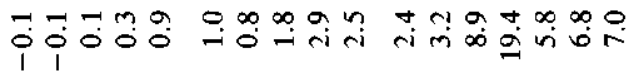

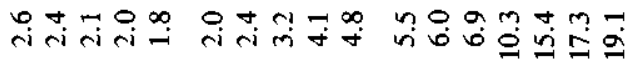

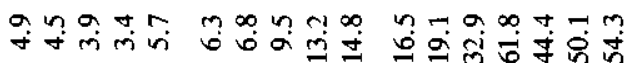

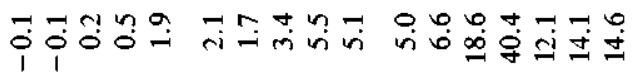

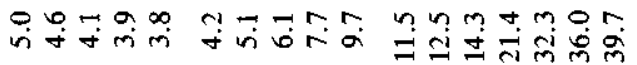

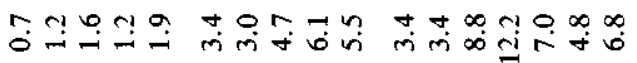

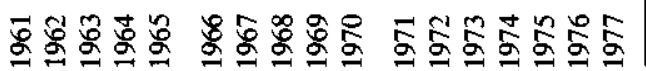




\subsection{The Total Taxation of the Corporate Sector}

We now turn to the crucial issue of corporate debt. Although inflation reduces the real value of outstanding corporate debt, this gain by corporations is not taxable income. Equivalently, corporations subtract nominal instead of real interest payments in calculating taxable profits. A number of previous writers on the relation between inflation and corporate taxes have concluded that the corporate tax saving from the exclusion of real gains on the debt is sufficient to offset the additional tax caused by the mismeasurement of depreciation and inventory profits. ${ }^{10}$ This has been interpreted as implying that inflation has no net effect on the taxation of corporate source income.

These conclusions are misleading because they are based on consideration of only some of the taxes levied on corporate source income. The basic issue is not the effect of inflation on the corporations' tax liability but the effect of inflation on the taxation of capital used in the corporate sector. It is important to look through the corporation to the individuals and institutions that provide the equity and debt capital. The total tax on corporate source income includes taxes paid by the owners of corporate securities on dividends, interest payments, and capital gains. It is this total tax rather than the tax levied at the corporate level alone that affects economic incentives.

This perspective is particularly important with respect to interest payments. While corporations are permitted to deduct nominal rather than real interest payments, lenders are obliged to pay taxes on nominal interest receipts. The effect of inflation on the total taxation of interest income depends on the relative magnitude of the tax rates facing corporate borrowers on one hand and those who lend to corporations on the other. If the tax rate of corporate borrowers exceeds that of lenders, total tax payments fall. Otherwise, tax revenues rise. ${ }^{11}$

The effect of dividend and capital gains taxes must also be considered. The mismeasurement of income which gives rise to extra corporate tax payments reduces dividends and retained earnings. This causes a reduction in noncorporate taxes which partly offsets the increase in corporate taxes. Inflation also increases nominal capital gains but not real capital gains, leading to increases in noncorporate tax payments. A full calculation of the effects of inflation on the taxation of corporate source income requires taking account of these effects. The analysis that we present in this section shows that the relevant weighted average of the marginal tax rates paid by the individuals and institutions that lend to nonfinancial

10. For example, Shoven and Bulow (1976) and Cagan and Lipsey (1978) reached this conclusion.

11. The potential balancing between borrowers and lenders is stressed in theoretical models of the effect of inflation in Feldstein (1976; chap. 3 above), and Feldstein, Green, and Sheshinski (1978; chap. 4 above). 
corporations is even greater than the marginal rate of tax that is saved by corporations and their shareholders because of the overstatement of true interest payments. More specifically, we shall show that the relevant marginal tax rate for those who lend to corporations is 0.420 while the relevant combined rate of corporations and their shareholders as borrowers is $0.404 .{ }^{12}$ Ignoring the real gains and losses on corporate debt therefore results in an underestimate of the total excess tax on corporate source income that is caused by inflation. However, since the difference between the effective marginal rates of the borrowers and the lenders is quite small, the whole issue of the real gains and losses on debt (or the mismeasurement of interest payments) can be ignored without distorting the measurement of the additional tax caused by inflation. ${ }^{13}$

Although we believe it is important to examine the effect of inflation on the total tax burden on corporate source income, we shall also analyze the effect of inflation on the tax burden of the corporations and their shareholders. Our calculations, presented in section 8.3 show that the extra taxes that the corporations and their shareholders pay because of inflation substantially exceed the amount they save by ignoring their inflationary gains on their net debts. Thus whether one looks at total capital income or only at the equity investors, the data show that inflation raises the effective tax burden.

\subsubsection{Noncorporate Taxation of Equity Income}

Owners of corporate equity pay dividend taxes on corporate income if it is distributed or capital gains taxes if it is retained. The rates at which these taxes are levied depend on the holder. Individuals, for example, pay taxes on dividend income at regular income tax rates but pay capital gains taxes at much lower effective rates. Different financial institutions pay taxes at varying rates on capital income. As noted below, pension income is essentially untaxed while certain institutions (e.g. life insurance companies) actually face higher capital gains tax rates than dividend tax rates.

The first step in finding the effective tax rate paid on equity income is to determine the distribution of ownership of corporate equity. Table 8.2 displays the pattern of ownership of corporate equity at the end of 1976 as reported in the official flow of funds accounts prepared by the Board of Governors of the Federal Reserve System. The bulk of the equity is held by households with significant fractions held by pension funds and life insurance companies. A small portion is held by other financial institu-

12. The reason why the combined effective marginal tax rates for corporations and their shareholders is less than the 48 percent corporate rate is that the extra corporate tax payments lead to a reduction in taxes on dividends and retained earnings.

13. Since the lenders and borrowers are not the same individuals, inflation does cause a redistribution of net income among individuals and institutions. 


\begin{tabular}{|c|c|c|c|}
\hline \multirow[b]{2}{*}{ Class of Investor } & \multirow{2}{*}{$\begin{array}{l}\text { Value of } \\
\text { Holdings } \\
\text { ( } \$ \text { billions) }\end{array}$} & \multicolumn{2}{|c|}{ Tax Rates on } \\
\hline & & Dividends & $\begin{array}{l}\text { Capital } \\
\text { Gains }\end{array}$ \\
\hline Households & 566.4 & .39 & .05 \\
\hline Pension tunds ${ }^{\mathrm{a}}$ & 112.9 & 0 & 0 \\
\hline Life insurance & 34.3 & .072 & .15 \\
\hline Other insurance & 17.1 & .072 & .15 \\
\hline Mutual banks & 4.4 & .072 & .15 \\
\hline Commercial banks & .9 & .072 & .15 \\
\hline Other $^{b}$ & 46.8 & 0 & 0 \\
\hline Total & 782.8 & .287 & .047 \\
\hline
\end{tabular}

SOURCE: Flow-of-funds data for 1976. Tax rate calculations are described in the text. Note that tax rates represent conservative assumptions rather than estimates of most likely values.

a. Includes both private pensions and the retirement funds of state and local government.

b. Comprised primarily of foreign holdings.

tions. The second and third columns of the table indicate the marginal tax rates on dividends and capital gains for each type of stockowner. We assume that retained earnings are taxed at the capital gains tax rate ${ }^{14}$

We estimate that under 1976 law, the average marginal tax rate on individual dividend receipts was 39 percent. $^{\text {ts }}$

Individual capital gains are taxed at half the statutory rate on dividends. However, gains are taxed only if realized and the effective rate is reduced by the postponement of realization. ${ }^{16}$

Bailey (1968) has estimated that each of these factors approximately halves the effective tax rate on capital gains. Hence we assume a 5 percent

14. Assuming that retained earnings are taxed at the capital gains rate involves the implicit assumption that each dollar of retained earnings raises share prices by $\$ 1.00$. Although Bradford (1979) and Auerbach (1978; appendix to chap. 4 above) have challenged this assumption by a suggesting that the existing tax rules and dividends make the equilibrium value of retained earnings less than one, the possibility of distributing the corporate net worth through mergers and stock repurchases implies that even existing tax rules do not keep the value of retained earnings below one. While the issue is still in flux, we adopt the traditional assumption that each dollar of retained earnings raises the share prices by $\$ 1.00$. See also Feldstein and Green (1979).

15. The marginal tax rate was found by using the NBER's TAXsIM model to estimate the additional tax payments arising from a $1 \%$ increase in dividend payments. The TAxSIM model is described in Feldstein and Frisch (1977). We allow for an estimated 7\% of equity held by institutions which are not taxed but which are included by the flow of funds statistics in the household sector; this estimate of institutional ownership is derived from the SEC Statistical Bulletin.

16. Individuals who realize capital gains are taxed on the gain which occurred while they were holding the asset. Hence capital gains which accrue on assets which are passed at death completely avoid taxation. This is because the new owner is permitted to "step up" his basis for future tax liabilities. 
tax rate on capital gains. This estimate is conservative because we ignore the taxes paid under the minimum tax and preference income provisions of the tax law.

We assume that no taxes are levied on the equity income of pension funds. In fact, pension recipients do pay taxes on pension income upon receipt. The effective rate is low, however, because the tax liability is postponed and because the recipients generally have low marginal tax rates during retirement. Moreover, increased pension returns may be associated with reduced employer contributions rather than increased benefits. In order to be conservative in our estimate of the effective tax rate on capital income, we assume a zero effective tax rate on pension income. ${ }^{n}$

Life insurance companies and commercial banks are taxed at corporate tax rates on dividends and capital gains. They are permitted to exclude 85 percent of dividends because of the intercorporate dividend exclusion. Hence, their effective marginal tax rate on dividend income is 7.2 percent.$^{18}$ These institutions are taxed at a 30 percent statutory rate on capital gains realizations. We assume an effective rate of 15 percent on such gains because of the effect of deferral. Unlike our treatment of individuals, we assume that all gains are eventually realized.

A weighted average of the effective tax rates provides our estimates of the overall marginal effective rates on dividends and retained earnings. In order to determine the noncorporate tax rate on all equity income, it is necessary to determine how corporate profits are divided between dividends and retained earnings. We estimate this payout ratio by using the average payout ratio over the past decade. ${ }^{19}$ The share of total profits going to dividends over this period was 46.1 percent, implying an overall tax rate on equity income of 15.7 percent.

Using this figure it is possible to find the total tax increase on equity due to a mismeasurement of corporate profits. Suppose that corporate taxable income is increased by a single dollar with no change in real income. The corporation pays 48 cents more in taxes. Shareholder income in the form of dividends and retained earnings is reduced by 48 cents, leading to a decline of 7.6 cents in shareholder tax payments. Hence, total tax payments rise by 40.4 cents. Thus, the marginal tax rate on mismeasured income is 40.4 percent. Calculations of the increase in corporate taxes

17. It can be argued that the tax treatment of pension income is equivalent to a consumption tax because income put into pensions escapes all tax until the pension is withdrawn and presumably consumed. On this view, the effective tax rate on pension dividend and interest income is zero.

18. This overstates the dividend tax rate for insurance companies because of the special rules applying to insurance companies.

19. In calculating the payout ratio, profits are adjusted for inflation effects on inventory and depreciation and on real net indebtedness. We implicitly assume that there are no "clinetele" effects, so that payout ratio is the same for the equity owned by different classes of investors. 
due to historical cost depreciation or false inventory accounting overstate by about 20 percent the true additional burden on the suppliers of equity capital.

\subsubsection{The Value of Corporate Interest Deductions}

Corporations are permitted to deduct nominal rather than real interest payments. Increases in inflation raise the corporations' interest deductions, thereby reducing corporate tax liabilities. Although the corporate tax rate is $\mathbf{4 8}$ percent, the overstatement of interest expenses reduces total tax payments by less than 48 percent. This occurs because the increase in after-tax corporate income results in an increase in noncorporate tax payments on dividends and capital gains. In section 8.2.1, we showed that the effective marginal tax rate on dividends and retentions is 15.7 percent; i.e., it was demonstrated that the equity owners' tax rate on "mismeasured" corporate income was $\mathbf{4 0 . 4}$ percent. This is the correct measure of the reduction in tax liabilities due to the deduction of nominal interest. It is this 40.4 percent rate that can be compared with the marginal tax rate of corporate debt holders in order to determine the effect of inflation on the taxation of interest income and expenses. In the next part of this section we consider the extra tax paid by the holders of corporate debt.

\subsubsection{The Tax on Corporate Debt Holders}

We now examine the extra taxes that the holders of corporate debt pay when interest rates rise in response to a higher rate of inflation. Equivalently, we estimate the amount by which their taxes would be reduced if the taxation of interest income were indexed. We also examine the extra taxes corporations pay on their interest-bearing financial assets. In table 8.3 we display the nonfinancial corporate sectors' interestbearing financial assets and liabilities at the end of 1976. The holders of these securities are shown in the different columns. These figures are derived directly from the official flow of funds accounts. The penultimate row provides the net corporate debt holdings of each class of investor, formed by aggregating the entries in the column. In order to calculate the effective tax rate on the holders of corporate debt, we find the weighted average of marginal tax rates for each investor class.

Before describing our estimates of the specific marginal tax rates, several features of table 8.3 deserve comment. First, most corporate debt is not in the form of bonds. Nearly half is comprised of bank borrowing and mortgages. Second, only a small proportion of corporate interest payments, less than 15 percent, goes to individuals. The largest portion goes to commercial banks. Third, it is important to recall that corporations themselves hold a large quantity of interest-bearing financial assets. 
Inflation leads to the increased tax liabilities on increased income from these assets. ${ }^{20}$

Our estimate of the marginal tax rate facing each class of creditors is shown in the bottom row of table 8.3. These estimates are only approximate since the laws governing financial institutions are quite complex and since all of the desired information is not available. Fortunately, the estimates that are most uncertain generally apply to only small quantities of debt. When in doubt, we have selected relatively conservative assumptions. The rationale for each of our estimates now follows:

Households. According to the NBER TAxSIM model, the weighted average of the marginal tax rates on interest income is about 25 percent. However, this average includes bank deposit interest as well as interest on corporate securities. Since corporate bonds are held by more affluent taxpayers than ordinary bank account time deposits (see Projector and Weiss, 1966), the 25 percent overall figure for all interest payments is too low. We have selected a 35 percent tax rate on interest paid, thereby implying that household bondholders have lower marginal tax rates on average than household dividend recipients.

Pensions. These are conservatively treated as fully tax exempt, implying a zero marginal tax rate.

Commercial Banks. Commercial banks pay a 48 percent corporate income tax at the margin on interest receipts. Those interest receipts net of corporate tax are then subject to further taxes as dividends and retained earnings; we assume the same 15.7 percent rate for this equity income that we derived in section 8.2 .1 for the equity income of nonfinancial corporations. Combining the 48 percent and the 15.7 percent implies an overall tax on this equity income of 56.1. However, when the interest rates that banks charge rise, banks also raise the interest payments that they make to their depositors. To the extent that these interest payments rise, the banks do not pay extra taxes but their depositors do. Of course, there is no increase in the interest paid on demand deposits. We assume that interest rate ceilings constrain the increase in other interest rates to 0.3 percent for each 1 percent increase in inflation. ${ }^{21}$ When this is allowed for, the total marginal tax rate on corporations and their depositors is approximately 54 percent. $^{22}$

Mutual Savings Banks. In some cases, these banks pay the same 48 percent tax as ordinary corporations. However, mutual savings banks with a sufficient fraction of their assets in the form of local mortgages are

20. In some cases this leads to deductions for the issuers of the assets.

21. This assumption is based on a regression for the $1954-77$ period of the time deposit rate on the rate of inflation.

22. This assumes that demand deposits account for 38 percent of total bank liabilities and that the marginal tax rate on the depositors at commercial banks is 25 percent. 


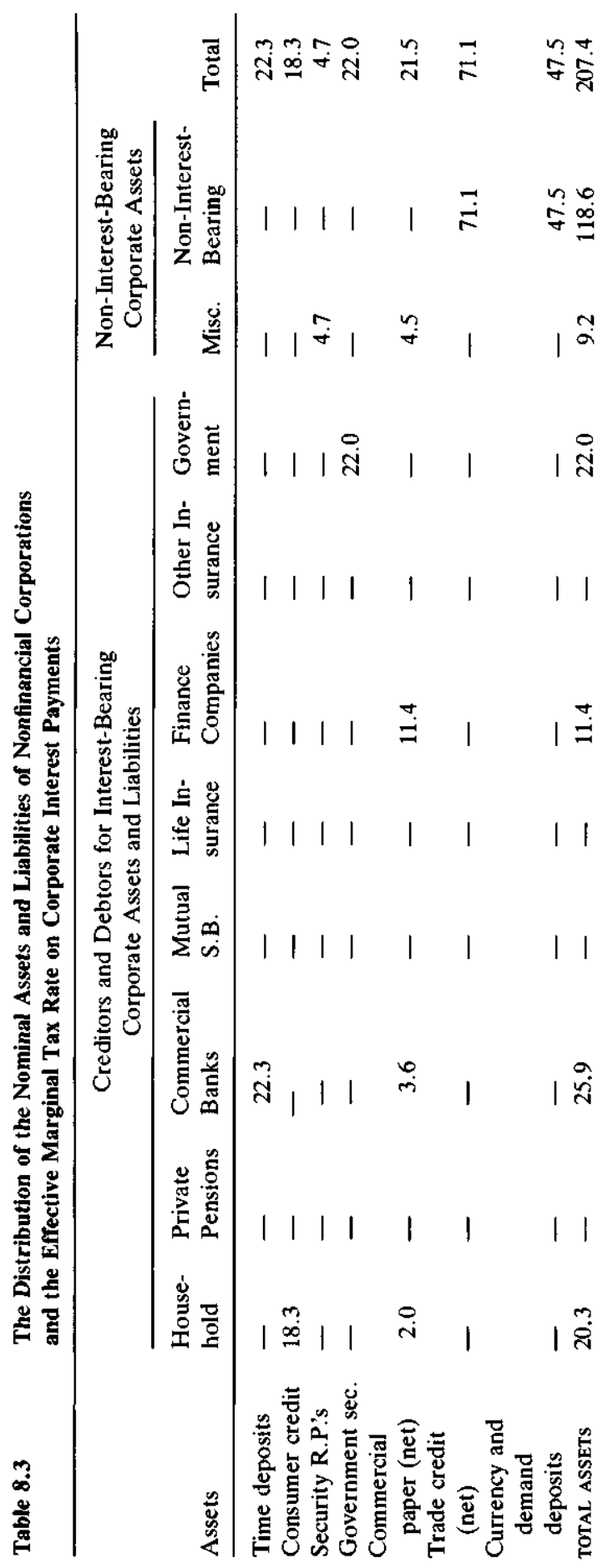




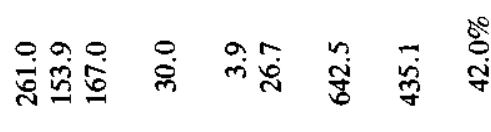

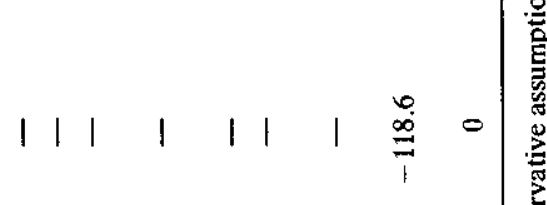

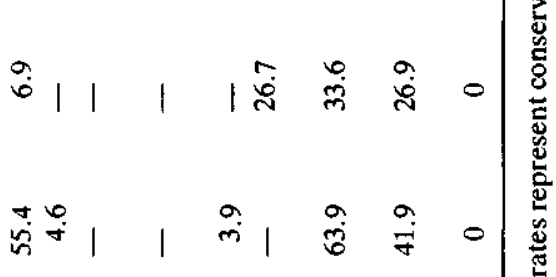

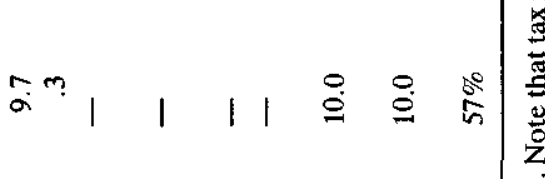

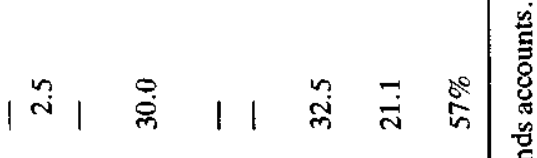

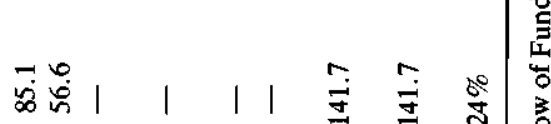

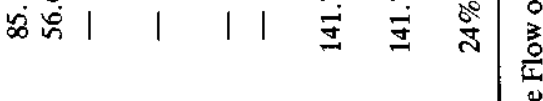

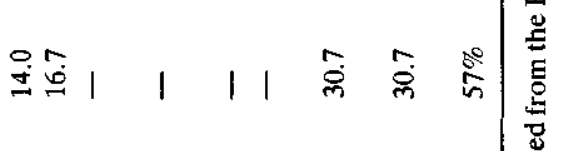

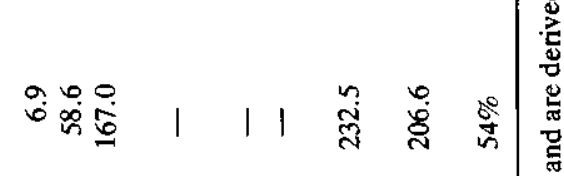

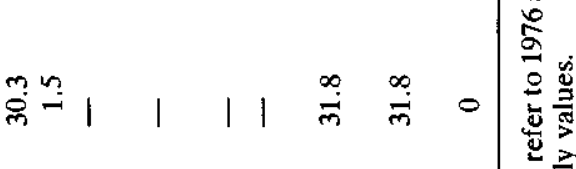

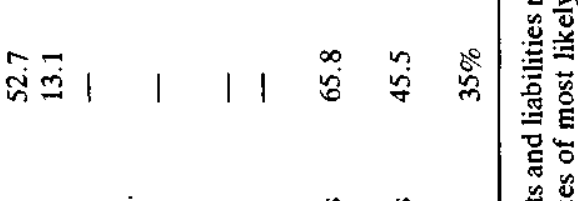

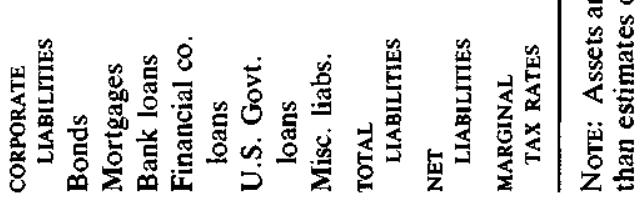


allowed to exclude a fraction of their portfolio income, a fraction that increases with the mortgage share. The overall effective rate must also reflect the extent to which mutual savings banks raise the interest rate they pay and the corresponding marginal tax rate of their depositors. We estimate a 24 percent overall rate for these institutions based on the assumption that about half of marginal income is successfully sheltered.

Life Insurance Companies. Life insurance companies are taxed according to the "Menge Formula" or "ten-to-one rule" which allows insurance companies to exclude a portion of their portfolio income before applying the 48 percent corporate tax rate (see Huebner, 1976, for a discussion of this tax rule). The procedure in the existing law is designed to separate investment income into an amount required to meet the funding requirements for existing insurance and a residual profit that is deemed taxable. To achieve this, life insurance companies pay tax on a percentage of income equal to ten times the difference between the average nominal yield on the portfolio $(i)$ and the nominal yield that the insurance commissioners deem to be the appropriately conservative yield to use in calculating required reserves $(s)$. Thus if the assets of the insurance company $(A)$ are invested at a nominal yield of $i$, the total tax liability of the company is $T=0.48[10(i-s)] i A$. The change in the effective tax rate caused by inflation depends on how $i$ and $s$ adjust. As we noted above, the nominal market yield $(i)$ generally rises point for point for expected inflation. In contrast, the regulatory authorities have not altered $s$ in response to inflation; historically, $s$ has remained close to 3 percent for the past 70 years. The marginal tax rate implied by this tax formula for increases in the interest rate is an increasing function of the initial marginal tax rate. Evaluating the marginal tax rate at the relatively conservative value of $i$ $=0.07$ implies a marginal tax rate of $0.57 .{ }^{23} \mathrm{We}$ use this value to be conservative; at higher initial interest yields, the effective marginal tax would be even greater. Note we are also conservative in ignoring the tax paid on dividends and retained earnings of the nonmutual life insurance companies.

Finance Companies and Other Insurance. These are taxed like ordinary corporations. Combining the 48 percent corporate rate with the additional tax on dividends and retained earnings yields an overall marginal tax rate of 57.1 percent on this type of income.

Government. We assume that government neither pays taxes on interest receipts nor deducts expenses for tax purposes. While increases in

23. Note that at $i=.07$, a $\$ 1,000$ portfolio earns $\$ 70$. With $s=.03$ only 40 percent of this or $\$ 28$ is taxed; the tax is $\$ 13.44$ and the net income is therefore $\$ 56.56$. Raising the interest rate to $i=.08$ implies earnings of $\$ 80$ but 50 percent or $\$ 40$ is taxable. The tax is thus $\$ 19.20$, leaving a net income of $\$ 60.80$. Note that an extra $\$ 10$ of gross interest raises net interest income by only $\$ 4.24$. The effective marginal tax rate is thus 57.6 percent. 
interest receipts may enable governments to reduce other taxes, there is no reason to suppose that capital taxes will be reduced. Moreover, other costs of government are increased by raising interest rates.

Miscellaneous. The interest on these assets is assumed to be untaxed. Note that "miscellaneous" includes assets and liabilities of the rest of the world so our no-tax assumption implies that no taxes are paid to either the U.S. or to foreign governments by foreigners owning bonds of U.S. corporations. It is clear that our assumption that all of this income is untaxed is very conservative.

In order to calculate the marginal tax rate on interest income, we have averaged the marginal tax rates shown in the final row of Table 8.3, weighting by the share of debt owned the class of investors' share of debt. The results imply a marginal rate of 0.420 on interest income.

This implies that inflation raises the taxation of interest income, since the tax rate that lenders pay exceeds that at which corporations deduct. Allowing in the overall calculation for the impact of inflation on debt thus actually strengthens the conclusion that inflation raises the effective taxation of capital income. This effect is, however, quite small. It is equal to 1.6 percent of net interest payments (the difference between the 42 percent of lenders and the 40.4 percent of corporate borrowers or about a half billion dollars per year). This is dwarfed by the depreciation and inventory effects described in the previous section.

While several of our estimated marginal tax rates are only approximate, they pertain to relatively small amounts of debt. It is unlikely that a more exact estimate of these numbers would alter our basic conclusion that the tax on those who lend to corporations is at least as great as the rate at which corporations and their owners can deduct interest payments.

\subsection{The Increased Taxation of Corporate Source Income}

The first section of this paper presented calculations of the additional tax paid by corporations because of the mismeasurement of depreciation and inventories. The current section extends that calculation in three significant ways to obtain the total increased tax on corporations, on equity owners, and on all sources of capital for nonfinancial corporations.

Our calculations show that inflation raised the total tax on the income of nonfinancial corporations by $\$ 32.3$ billion. This amount is substantially greater than the $\$ 26.1$ billion additional tax paid by corporations themselves because of the mismeasurement of depreciation and inventory profits.

We begin by analyzing the several effects of inflation in 1977 . Estimates for the years since 1954 are then presented. 


\subsubsection{An Analysis for 1977}

We proceed in three steps to calculate the total additional taxes on corporate source income in 1977 . We first calculate the excess tax paid by the corporation itself, recognizing the effect of not taxing the real gains on debt as well as the effect on depreciation and inventory profits. We then extend this to obtain the total excess tax paid by equity owners, including the effect on the tax liabilities of the corporations and the shareholders. Finally, we extend the calculation to the total excess tax including the tax paid by those who lend to the nonfinancial corporations.

The calculations in section 8.1 showed that historic cost depreciation and the existing inventory accounting practices added $\$ 26.1$ billion to the 1977 tax liabilities of nonfinancial corporations. In 1977 these corporations had net interest bearing liabilities ${ }^{24}$ of $\$ 592.2$ billion and noninterest-bearing assets (primarily cash and net accounts receivable ${ }^{25}$ ) of $\$ 130.9$ billion. Their net nominal liabilities were thus $\$ 461.3$ billion. Since the 1977 inflation rate was 6.8 percent (the December-to-December increase in the CPI), these corporations had a real gain of $\$ 31.4$ billion on their net liabilities. Excluding the gain from the corporations' taxable income saved them $\$ 15.1$ billion in corporate tax. These tax savings thus offset approximately one-half of the $\$ 26.0$ billion of extra tax caused by the existing tax treatment of inventories and debt. Inflation caused corporations to pay an extra tax of $\$ 11$ billion in 1977 .

The extra tax paid by the equity owners of the corporations differs in two ways from the extra tax paid by the corporations. First, as we discussed earlier, the extra tax paid at the corporate level leaves less income to be taxed as dividends. With a dividend payout rate of 0.46 and effective marginal tax rates of 287 on dividends and 0.047 on retained earnings, the $\$ 11$ billion of extra corporate tax reduces shareholders own taxes by $\$ 1.7$ billion. Second, the shareholders must eventually pay capital gains tax on the nominal increase in the market value of the company that results from inflation. Since this nominal increase in value is over and above the real increase due to retained earnings the extra tax paid on this nominal gain represents an extra tax caused by inflation. We shall assume that the nominal gain can be approximated by the product of the inflation rate and the real value of corporate assets. ${ }^{26}$ The relevant marginal rate of tax on these accrued nominal gains is the effective capital gains tax rate of 0.047 . The real value of the physical assets of these

24. See section 8.2 for a description of the composition of this net amount. Note that $\$ 592.2$ billion is net of the interest-bearing assets of these firms.

25. These assets also include Treasury bills and other federal government securities that bear interest since the important distinguishing feature of these "non-interest-bearing assets" is that private individuals and institutions do not pay any interest on them.

26. The actual nominal gain caused by inflation is very hard to disengage from other changes in market value. Theoretical considerations imply that a change in the expected rate of inflation will cause an inverse change in the market valuation ratio which then slowly returns to its equilibrium value (see Feldstein, $1980 \mathrm{~b}$; chap. 10 below). 
corporations (plant and equipment, inventories and land) ${ }^{27}$ in 1977 was $\$ 1,684$ billion. The inflation rate of 6.8 percent and the tax rate of 0.047 imply an additional capital gains tax of $\$ 5.3$ billion. The total excess tax on the equity owners of the nonfinancial corporations is therefore the sum of three terms: the $\$ 11$ billion of extra corporate income tax minus the $\$ 1.7$ billion resulting reduction in personal taxes plus the capital gains tax of $\$ 5.3$ billion. Inflation thus induced a net extra tax of $\$ 14.6$ billion on corporations and their owners in 1977.

To obtain the total additional taxation on corporate source income that is caused by inflation, the additional taxation of corporate creditors must be added to this $\$ 14.6$ billion. The net financial capital supplied by the creditors of these corporations was $\$ 595.2$ billion. ${ }^{28}$ The inflation rate of 6.8 percent imposed a real loss of $\$ 40.5$ billion that should have been offset against the interest income of the creditors. The effective marginal tax rate of 0.420 on interest income implies an additional taxation of $\$ 17$ billion. ${ }^{29}$

Combining this $\$ 17$ billion with the $\$ 14.6$ billion implies an extra tax on corporations and their owners of $\$ 31.6$ billion. This additional tax on corporate source income was 54 percent of the corporate income tax liabilities of $\$ 59$ billion and 34 percent of the combined corporate, shareholder, and lender tax liabilities of $\$ 93$ billion. Stated in yet a different way, the excess tax of $\$ 31.6$ billion caused by inflation is equivalent to an additional wealth tax or capital levy of 2 percent on the real corporate assets of $\$ 1,684$ billion. Since these corporations earn between 10 and 12 percent on their real assets, ${ }^{30}$ this extra tax absorbs between one-sixth and one-fifth of pretax real earnings.

\subsubsection{The Period Since 1954}

This same framework can be used to calculate the additional tax caused by inflation in each year since $1954 .{ }^{31}$ Since we do not have a detailed flow-of-funds calculation of the sort presented in section 8.2 for each year, we shall use the same effective marginal tax rates for all years. The calculations therefore represent the additional tax that would have been caused for each year if the 1976 statutory tax rates and composition of creditors and debtors had prevailed; differences that result from using actual statutory rates and ownership information would be small relative to the differences over time caused by the changing history of inflation.

Table 8.4 traces the evolution of the inflation-generated additional

27. The data came from Von Furstenberg (1977).

28. We ignore the corporate assets in the form of government securities and net accounts receivable because these do not represent the supply of financial capital by private investors.

29. We neglect here the capital gains or losses accruing to firms and bondholders in existing debt when the interest rate changes.

30. See Feldstein and Summers (1977).

31. These are additional taxes due to inflation in the sense that they would not have been paid if the system were fully indexed. 


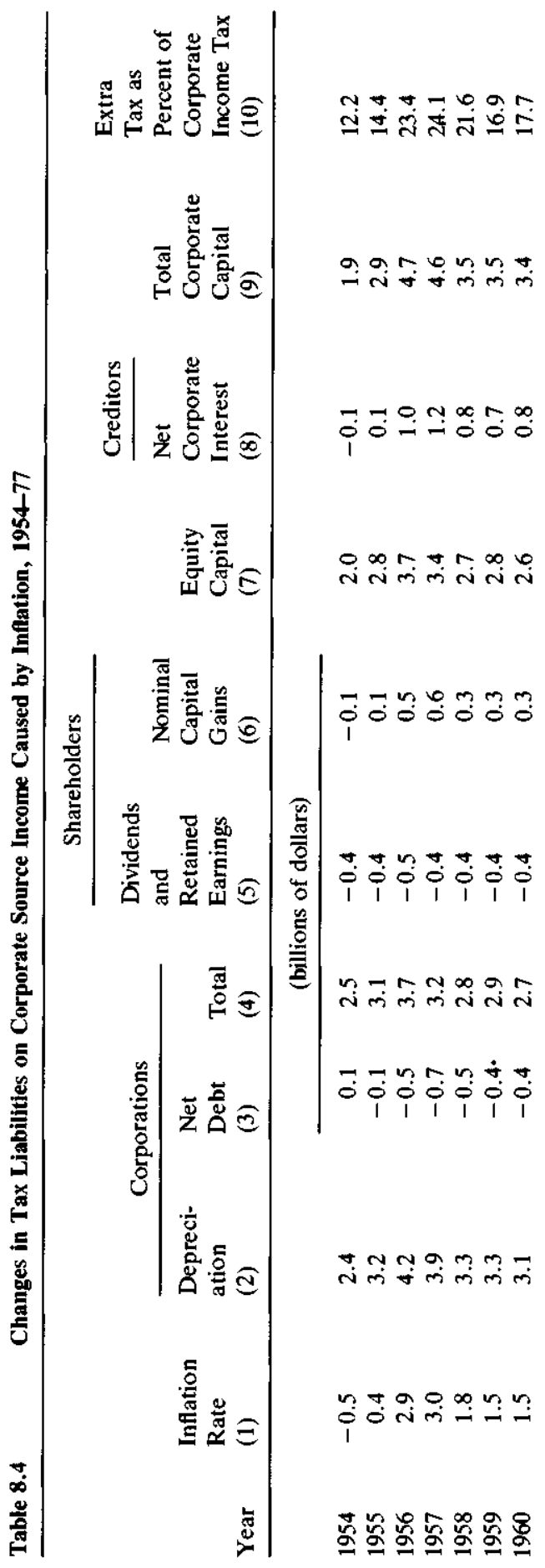




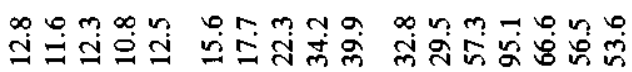

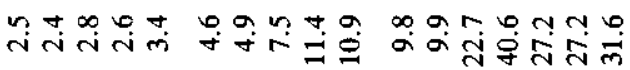

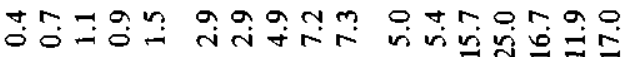

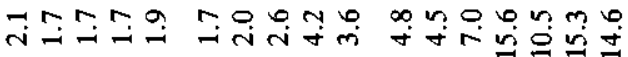

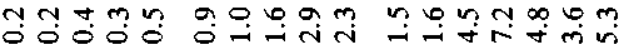
व

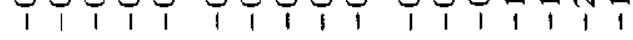

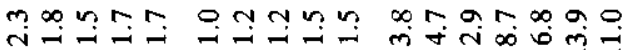
"

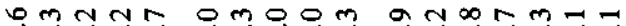

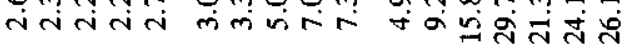

m

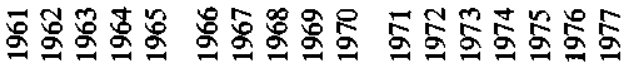


taxation of corporate source income between 1954 and 1977. Column 2 repeats the figures from table 8.1 , column 7 , of the excess tax at the corporate level due to the mismeasurement of depreciation and inventory profits. The corporate tax savings due to ignoring the real gains on net corporate debt are presented in column 3 . It is worth noting that the additional tax paid to the mismeasurement of depreciation and inventory profits always exceeds the tax savings on the debt gains. The net excess at the corporate level, presented in column 4, remains relatively low (less than $\$ 5$ billion) until 1974 when it jumped to $\$ 8.7$ billion.

The reduced taxation of dividends and retained earnings due to higher corporate tax payments is shown in column 5 and the capital gains tax liability on the nominal capital gains caused by inflation is shown in column 6 . Combining columns 4,5 , and 6 gives the net increase in the taxation of equity capital presented in column 7 . This additional tax on equity income remained less than $\$ 5$ billion until 1970 but has exceeded $\$ 10$ billion annually since 1974 . The additional tax on equity income since 1970 has totalled more than $\$ 80$ billion.

Column 8 presents the very important additional tax on the individuals and institutions that provide debt capital to the nonfinancial corporations. This excess tax on lenders reached $\$ 5$ billion in 1968 and exceeded $\$ 15$ billion in 1973 . The additional tax on those who lent to nonfinancial corporations has exceeded $\$ 100$ billion in the brief period from 1970 to 1977.

The total additional tax on corporate source income caused by inflation is shown in column 9. Three things should be noted about these figures. First, this total extra tax caused by inflation exceeds the extra tax paid by corporations because of the mismeasurement of depreciation and inventory profits (column 2). Focusing exclusively on the extra corporate taxes paid because of the mismeasurement of depreciation and inventory profits is therefore a conservative evaluation of the total inflationary impact. Second, the total excess tax remained less than $\$ 5$ billion a year until 1966, doubled by 1970 and doubled again by 1973 . The excess tax has exceeded $\$ 20$ billion a year since 1973 . Third, the total excess tax on corporate source income has exceeded $\$ 180$ billion in the period between 1970 and 1977.

Finally, column 10 states the total excess tax on corporate source income as a percentage of the corporate tax liability. Although the extra tax remained less than one-sixth of corporate income tax payments until the mid-1960s, it then quickly rose to more than one-third of the corporate income tax. For the final five years, the excess tax payments have been more than 50 percent of corporate tax liabilities. 


\subsection{The Effective Tax Rate on Corporate Source Income}

This section presents our estimates of the total effective tax rate on the real capital income earned in the corporate sector. Our calculations show that the total tax on corporate source income in 1977, including the tax liabilities of shareholders and lenders as well as of the corporations themselves, was $\$ 91.8$ billion, an effective tax rate of 67 percent on the real pretax income of the nonfinancial corporate sector. The data show that this 67 percent represents a substantial increase in the effective tax rate over the past decade and a return to the effective tax rates of the mid-1950s.

The substantial increase in the effective tax rate despite statutory reductions reflects the impact of inflation. The $\$ 32.3$ billion of extra tax caused by inflation in 1977 accounts for more than one-third of the total tax on corporate source income, raising the effective total tax rate from 43 percent to 66 percent. The extra tax caused by inflation has thus offset all of the accelerated depreciation and other legislated tax reductions during the past two decades.

\subsubsection{The Effective Tax Rate in 1977}

The best measure of the tax burden on corporate source income is the ratio of the total tax paid on such income-including the taxes paid by shareholders and lenders as well as by the corporations-to the total real income available before tax for the shareholders and creditors. The official national income estimate of 1977 profits with the inventory valuation adjustment and capital consumption adjustment was $\$ 113.9$ billion. Net nominal interest payments by nonfinancial corporations were $\$ 33.7$ billion. It seems at first that the total pretax income available for shareholder and creditors could be obtained by simply adding these adjusted profits and net interest on the grounds that it is unnecessary to adjust interest payments for inflation since any correction to nominal interest expenses by the corporation would required an equal correction to nominal receipts by creditors. Although this is a generally correct principle, one further modification is required. A significant fraction of the corporations' financial assets are not liabilities of investors but of the government or of the corporations' customers. When inflation lowers the real value of these assets, the loss to the corporations is a gain to the government and to the corporations' customers and not to individual or institutional investors. The corporations' loss on these financial assets should therefore be subtracted from other corporate profits. In 1977, these assets were $\$ 130.9$ billion, the inflationary loss was therefore $\$ 8.9$ billion. The 1977 total pretax corporate sector income available for shareholders and creditors was the refore $\$ 138.7$ billion. 
Our estimated total tax of $\$ 91.8$ billion on this income consists of five components. (1) The largest of these is the corporate income tax payments of $\$ 59$ billion. This alone represents an effective tax rate of $\mathbf{4 2 . 5}$ percent on total corporate source income. (2) Dividends in 1977 were $\$ 39.1$ billion; an effective tax rate of 0.287 on dividends implies a tax liability of $\$ 11.2$ billion $^{32}$ and adds 8.1 percent to the effective tax rate. (3) The national income account estimate of $\$ 16$ billion of retained earnings ${ }^{33}$ ignores the real gain on outstanding debt. With a net debt of $\$ 461.3$ billion and a 6.8 percent inflation rate, the additional real retained earnings were $\$ 31.4$ billion. The total retained earnings of $\$ 47.4$ billion are eventually subject to capital gains taxation with an effective tax rate of 0.047 ; this adds $\$ 2.2$ billion to the total tax and 1.6 percent to the effective tax rate. (4) An additional capital gains tax liability results from the nominal increase in the value of corporate assets that accompanies a general rise in the price level. We abstract from the particular market fluctuations of 1977 and calculate that the real capital stock with an initial value of $\$ 1,684$ billion rose by 6.8 percent. With a tax rate of 4.7 percent, this nominal increase implies an effective tax of $\$ 5.4$ billion, adding 3.9 percent to the total effective tax rate. (5) Finally, the nominal interest payments of $\$ 33.7$ billion were taxable income of the creditors. With a tax rate of 0.42 , these interest payments involve a tax liability of $\$ 14.2$ billion, adding 10.2 percent to the effective tax rate. ${ }^{34}$ The total of these five figures of tax payments is thus $\$ 92$ billion for a total effective tax rate of 66.3 percent.

Before turning to a comparison of 1977 with earlier years, it is useful to contrast the actual effective tax rate of 66.3 percent with several alternative rates that are frequently cited. Perhaps the most common measure of the corporate tax burden is the ratio of the $\$ 59$ billion corporate income tax to the conventionally measured corporate profits of $\$ 143.5$ billion; the resulting rate of 41.1 percent is a gross underestimate of the actual total rate. An alternative and more sophisticated rate is the ratio of the corporate income tax to the sum of corporate profits with the inventory valuation and capital consumption adjustments ( $\$ 113.9$ billion) plus the real gains on the net corporate debt ( $\$ 31.4$ billion); the resulting rate of 40.6 percent is again less than two-thirds of the total burden. These calculations underline the importance of looking beyond the corporation

32. This calculation uses our estimated marginal tax rate on dividends to measure the average tax rate on dividends. This causes an overstatement of the tax llabllity, but the error is likely to be very small.

33. This is the official figure for the undistributed profits corrected for the inventory valuation and capital consumption adjustments.

34. We are again using an estimated marginal tax rate as an average tax rate on this income. This causes some overstatement, particularly for life insurance companies. Adjusting this to use an average rather than marglnal tax rate for life insurance companies might reduce the tax by up to $\$ 2$ billion dollars. 
to the shareholders and creditors in order to obtain a correct picture of total tax burdens on capital used in the corporate sector.

\subsubsection{Variations in the Effective Total Tax Rate Since 1954}

Table 8.5 traces the variations in the effective total tax rate on corporate capital since 1954 . The total real income presented in column 1 is the sum of real profits as measured by the national income statistics and net nominal interest payments with an adjustment for corporate losses on government assets and net accounts receivable.

Actual corporate tax liabilities as a percentage of this total real income have declined nearly one-fifth since the mid-1950s. Moreover, there has

The Effective Tax Rate on Capital Income of the Nonfinancial Corporate Sector

\begin{tabular}{|c|c|c|c|c|c|c|c|}
\hline \multirow[b]{3}{*}{ Year } & \multirow[b]{3}{*}{$\begin{array}{l}\text { Total Real } \\
\text { Income } \\
\text { (billions } \\
\text { of dollars) } \\
\text { (1) }\end{array}$} & \multicolumn{6}{|c|}{ Taxes as a Percentage of Total Real Income } \\
\hline & & \multirow[b]{2}{*}{$\begin{array}{l}\text { Corporate } \\
\text { Income } \\
\text { Tax } \\
(2)\end{array}$} & \multicolumn{4}{|c|}{ Taxes on Shareholders and Creditors } & \multirow[b]{2}{*}{$\begin{array}{l}\text { Total } \\
(7)\end{array}$} \\
\hline & & & $\begin{array}{l}\text { Dividends } \\
\text { (3) }\end{array}$ & $\begin{array}{l}\text { Real } \\
\text { Retained } \\
\text { Eamings } \\
\text { (4) }\end{array}$ & $\begin{array}{l}\text { Nominal } \\
\text { Capital } \\
\text { Appreci- } \\
\text { ation } \\
(5)\end{array}$ & $\begin{array}{l}\text { Interest } \\
\text { Income } \\
\text { (6) }\end{array}$ & \\
\hline 1954 & $\$ 30.4$ & 51.6 & 7.8 & 2.0 & -0.2 & 2.3 & 63.5 \\
\hline 1955 & 39.8 & 51.1 & 6.8 & 2.1 & 0.2 & 1.8 & 61.9 \\
\hline 1956 & 36.5 & 54.8 & 8.0 & 2.1 & 1.3 & 2.1 & 68.4 \\
\hline 1957 & 35.6 & 53.4 & 8.6 & 2.3 & 1.6 & 2.7 & 68.5 \\
\hline 1958 & 31.8 & 50.6 & 9.3 & 2.2 & 1.1 & 3.7 & 67.0 \\
\hline 1959 & 42.0 & 49.2 & 7.4 & 2.2 & 0.7 & 3.3 & 62.8 \\
\hline 1960 & 40.2 & 47.7 & 8.3 & 2.2 & 0.7 & 3.8 & 62.8 \\
\hline 1961 & 41.1 & 47.4 & 8.3 & 2.1 & 0.3 & 4.2 & 62.2 \\
\hline 1962 & 48.7 & 42.4 & 7.6 & 2.4 & 0.6 & 4.1 & 57.1 \\
\hline 1963 & 53.8 & 42.4 & 7.6 & 2.5 & 0.7 & 3.9 & 57.1 \\
\hline 1964 & 61.2 & 39.1 & 7.3 & 2.6 & 0.5 & 3.8 & 53.3 \\
\hline 1965 & 70.9 & 38.3 & 7.1 & 2.7 & 0.7 & 3.8 & 52.5 \\
\hline 1966 & 76.2 & 38.7 & 6.9 & 2.8 & 1.2 & 4.3 & 53.9 \\
\hline 1967 & 73.8 & 37.5 & 7.4 & 2.8 & 1.3 & 5.2 & 54.2 \\
\hline 1968 & 78.7 & 42.7 & 7.6 & 2.8 & 2.0 & 5.6 & 60.8 \\
\hline 1969 & 74.9 & 44.5 & 8.0 & 2.8 & 3.0 & 7.7 & 66.0 \\
\hline 1970 & 64.2 & 42.5 & 9.0 & 1.2 & 3.5 & 11.7 & 67.8 \\
\hline 1971 & 73.7 & 40.5 & 7.9 & 1.1 & 2.1 & 10.7 & 62.3 \\
\hline 1972 & 88.0 & 38.0 & 7.2 & 1.4 & 1.8 & 9.6 & 58.0 \\
\hline 1973 & 90.2 & 43.9 & 7.7 & 2.1 & 5.0 & 11.3 & 70.0 \\
\hline 1974 & 76.2 & 56.0 & 10.0 & 2.1 & 9.4 & 17.2 & 94.9 \\
\hline 1975 & 100.2 & 40.8 & 8.4 & 1.7 & 4.8 & 13.6 & 69.3 \\
\hline 1976 & 126.3 & 42.5 & 7.4 & 1.4 & 2.9 & 10.7 & 64.9 \\
\hline 1977 & 138.7 & 42.5 & 8.1 & 1.6 & 3.9 & 10.2 & 66.3 \\
\hline
\end{tabular}


been no increase at all in this ratio between 1970 and 1977 . This has incorrectly led some observers to discount the argument that inflation raised real tax burdens on capital income.

The varying taxes on shareholders and creditors in columns 3 through 6 reflect variations in dividends, full retained earnings, inflationary appreciation, and interest payments. The same 1977 effective tax rates are assumed for each tax base; allowing for statutory changes would raise taxes on dividends and interest income in the earlier years and in those years but this effect would be relatively small.

The net result of these changes is shown in the total effective tax rate presented in column 7. Despite the decline in the relative corporate tax payments, the overall effective tax rate is as high now as it was in the mid-1950s. The effect of inflation has been powerful enough to offset the introduction of the investment tax credit, the cuts in the corporate tax rate, and the more rapid acceleration of depreciation. ${ }^{35}$

\subsection{Inflation and Corporate Tax Liabilities in Two-Digit Manufacturing Industries}

Although historic cost depreciation and existing accounting practices raise the tax liabilities of all corporations, their importance varies substantially among different industries. The current section presents information for each of the 20 two-digit manufacturing industries. For manufacturing as a whole, the additional taxes in 1976 caused by historic cost depreciation and existing accounting practices accounted for slightly more than half of all the federal tax liabilities of these firms. These additional taxes varied from less than 25 percent of actual taxes in a few industries to 100 percent of the taxes paid in several others. If the taxes are expressed as a percentage of the real value of capital used in these industries, the additional tax varies from less than 1 percent of capital to nearly 3 percent of capital. The very high tax rates that result in several of the industries make it particularly difficult for them to compete for capital. If these additional tax burdens persist, the allocation of capital among manufacturing industries will be substantially distorted by inflation.

Our analysis of the additional tax burdens of individual industries is based on information supplied by individual firms in their annual reports and 10-K forms. Beginning with 1976, the Securities and Exchange Commission has required the largest firms to supply information on replacement cost depreciation and on inflation-adjusted inventory gains as well as on historic cost depreciation and on their inventory profits as

35. We have ignored state and local taxation of corporate source income through corporate income rates, property taxes, and individual income rates. If these taxes were included, an increase in the effective tax rate would be observed and the current rate would exceed 66 percent. 
they are used for tax purposes. We use the differences between the inflation-adjusted and the unadjusted figures for depreciation and inventories to measure the overstatement of taxable profits. For each industry, we then compare the total additional tax liabilities implied by these overstated profits with the actual tax liabilities paid by the firms in our sample. We also calculate the additional tax payments as a percentage of the real value of the capital used by the sample firms in the industry. ${ }^{36}$ Finally, we use the ratio of sales by the sample firms to sales by all firms in the industry to estimate the total additional taxes caused in each industry in 1976 by historic cost depreciation and by prevailing accounting methods. ${ }^{37}$

Although the general approach of these calculations parallels the analysis of section 8.1 , there are several differences that should be borne in mind in interpreting the results. First, the information supplied by the firms represents consolidated accounts and not just the domestic activities that were analyzed in section 8.1. Because we are forced to include the overseas depreciation and inventory gains, we overstate the extent of overtaxation. Second, the firms provide the historic cost depreciation and replacement cost depreciation as alternative measures of "book" depreciation rather than "tax" depreciation. Since the straight-line "book" depreciation is less than the accelerated "tax" depreciation, this procedure causes us to understate the extent of overtaxation. The net effect of these two countervailing biases cannot be determined from the existing data but is unlikely to be large enough to distort the conclusions of the analysis. ${ }^{38}$

The sample of firms for which we have information represents approximately 50 percent of the total sales of manufacturing firms. Because of the nature of the SEC requirement, the sample consists exclusively of large firms. Moreover, the coverage varies substantially among the industries with a very much smaller fraction of sales in the samples for some industries than for others. The tables in this section indicate the number of firms in each sample and the fraction of sales that the sample firms represent. ${ }^{39}$

36. Estimates of the replacement cost value of plant, equipment, and inventories are also required by the SEC.

37. We do not analyze the effects of inflation on real indebtedness because data on the ownership of securities by industry does not exist. The results in section 8.2 suggest that this omission is not likely to have a great impact on the conclusions.

38. These results should be viewed with caution for other reasons. There appear to be wide variations in the methods used by firms in estimating replacement cost figures. There is no necessary correspondence between the depreciation lives used by firms and those used in the construction of the aggregate statistics presented above.

39. To estimate total sales in each industry, we use the Compustat file of 2,500 firms prepared by Standard and Poor. The 1,332 manufacturing firms in this file represent 1976 sales of $\$ 1,052$ billion or 87 percent of all manufacturing sales as estimated by the Federal Trade Commission. We use the Compustat file to estimate total sales by industry in order to be sure that firms are classified by industry in the same way as in our replacement cost sample. 
Table 8.6 presents information on the extent of reduced depreciation and the consequent additional taxation. The first two columns show the number of firms in the sample and the percentage of the total industry sales accounted for by the sample firms. The third column shows the understatement of depreciation, i.e., the difference between replacement cost depreciation and historic cost depreciation. The additional tax liability presented in column 4 is calculated by summing (for all the sample firms in the industry) 0.48 times each firm's understated depreciation up to the limit of the tax actually paid by the firm. Note that this is a very conservative statement of the additional tax for any firm in which the limit constrains our calculated amount because it assumes that no additional profits would have been earned even at a zero tax rate and disregards the possibility of carrying losses forward. Column 5 expresses the additional tax as a percentage of the total federal tax liability of the firms in the sample while column 6 states the additional tax liability as a percentage of the replacement cost value of the firms' real capital stock..$^{40}$ The remaining two columns are estimates for all the firms in the industry and not just the sample; they are obtained by rescaling the sample values for each industry by the ratio of total industry sales to sales in the sample.

The relative importance of the additional taxes that resulted from the understatement of depreciation varied substantially among the 20 individual industries. Column 5 shows that these additional taxes represented less than one-sixth of actual 1976 tax liabilities in 6 of the 20 industries. These are primarily nondurable goods (tobacco, apparel, printing and publishing, and leather and footwear) but also include the nonelectrical machinery and instruments industries. At the other extreme, there are four industries in which the additional tax represents more than threefourths of actual tax liabilities: primary metals, rubber, paper, and wood products.

A similar picture of very substantial variation emerges when the additional taxation is related to the replacement cost value of the firms' real capital stock (column 6 ). The additional tax varies from 0.4 percent of the real capital stock in the primary metals industry ${ }^{41}$ and 0.5 percent in the nonelectrical machinery industry to 2.0 percent in the paper industry and 2.8 percent in the wood products industry.

For manufacturing as a whole, the reduction in real depreciation totalled $\$ 18$ billion or half of the reduction for all nonfinancial corpora-

40. The real capital stock includes inventories as well as property, plant, and equipment but excludes financial assets and liabilities.

41. This tax is kept so low because the extra tax is assumed to be no greater than actual taxes paid which, in the case of primary metals, were kept low by extremely low real profits. 
tions that was discussed in section 8.1. Nondurable goods industries (SIC codes 20 through 29 ) accounted for 58 percent of this reduced depreciation or $\$ 10.4$ billion. Reduced depreciation in durable goods industries (SIC codes 30 through 39 ) was $\$ 7.6$ billion. The additional tax caused by the understatement of depreciation was $\$ 7.6$ billion, of which $\$ 4.9$ billion was in nondurable goods industries and $\$ 2.7$ billion was in durable goods industries.

Table 8.7 presents the combined effects of reduced depreciation and overstated inventory profits. The organization of the table parallels that of table 8.6. The results presented in column 5 show very substantial variation among industries in the importance of the extra tax as a percentage of actual taxes paid. In two of the industries (leather and nonelectrical machinery), the extra tax amounted to less than 20 percent of the actual tax paid. In contrast, four of the industries (wood and wood products; paper; rubber; and steel) would have paid no tax if depreciation had been calculated at replacement cost and if the artificial inventory profits were also eliminated. Column 6 confirms the picture of substantial variation among industries by comparing the additional tax to the replacement value of the real capital stock. The extra tax paid (as limited by the total tax paid) varied from less than 1 percent of the capital stock on the primary metals and nonelectrical machinery industries to nearly 3 percent of the capital stock in the food industry and in textiles.

For all manufacturing industries, the mismeasurement of depreciation and inventories totaled $\$ 27.1$ billion or 54 percent of the aggregate reported for all nonfinancial corporations in section 8.1. Of this $\$ 27.1$ billion total, 58 percent was accounted for by nondurable manufacturing. Note that this 58 percent is the same as the figure for depreciation only, implying that the mismeasurements of inventories and depreciation are distributed in the same way. The additional taxation for manufacturing firms totalled $\$ 11.3$ billion, of which $\$ 7.4$ billion was in the nondurable goods industries.

\subsection{Conclusion}

The tax laws of the United States were designed at a time when there was little or no inflation. The analysis in this paper has shown that, with the existing tax laws, inflation substantially increases the effective tax rate on capital income in the nonfinancial corporate sector. In contrast to earlier studies of the impact of inflation on corporate tax burdens, we have considered not only the tax paid by the corporations themselves but also the taxes paid by the individuals and institutions that supply capital to the corporate sector. This is particularly important for a correct treatment of corporate debt; our calculations indicate that the additional 


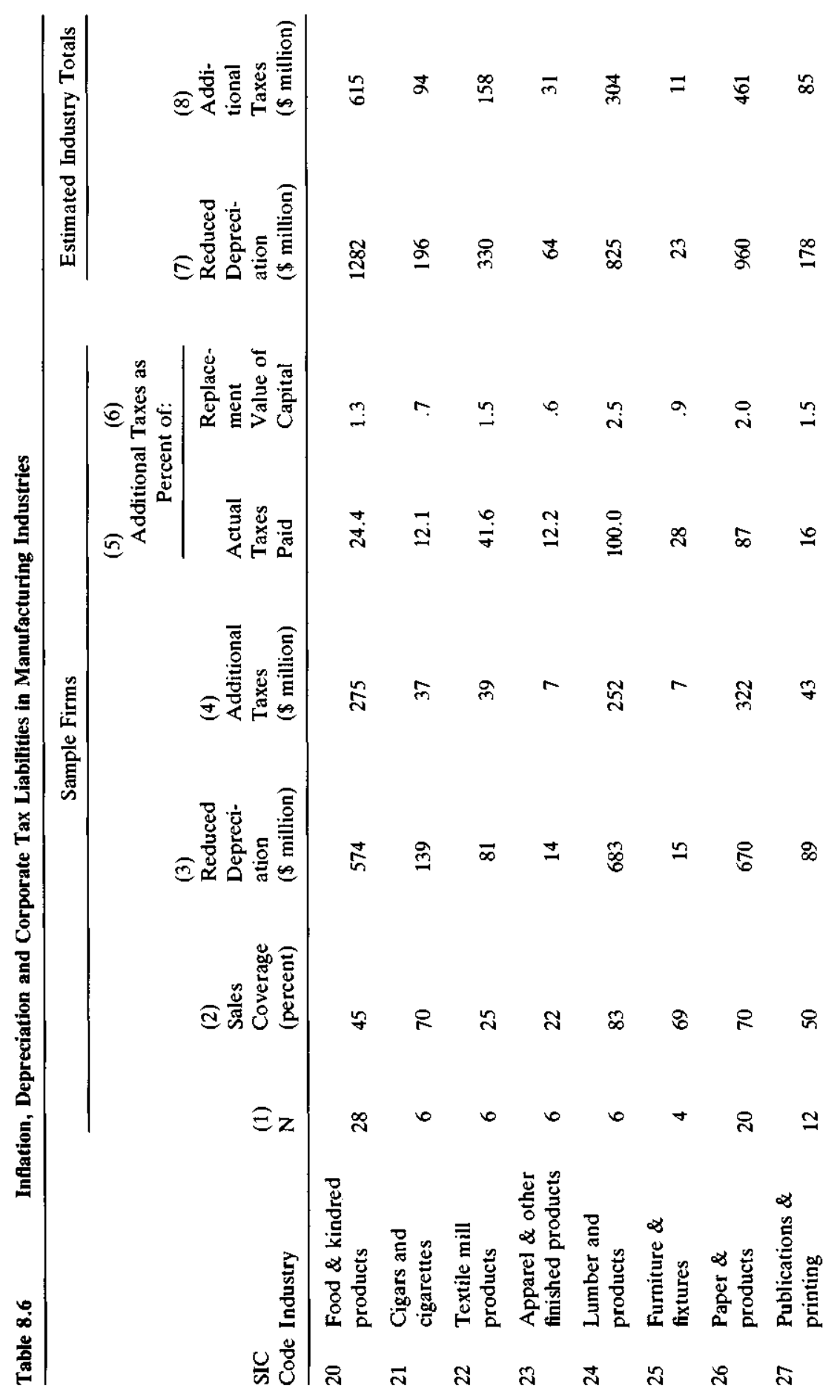




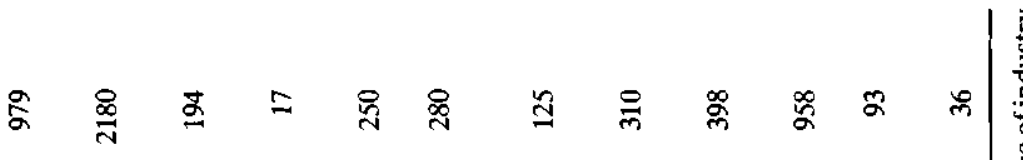

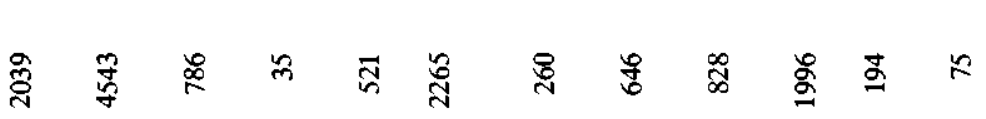

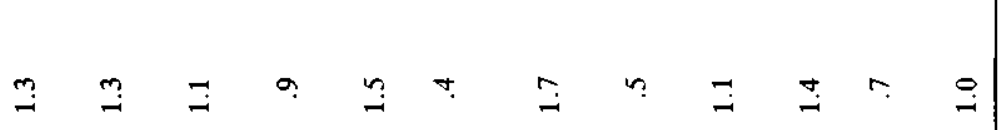

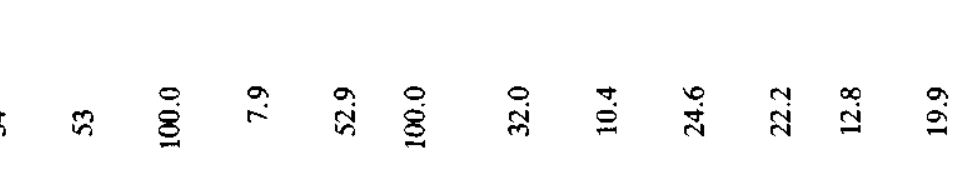

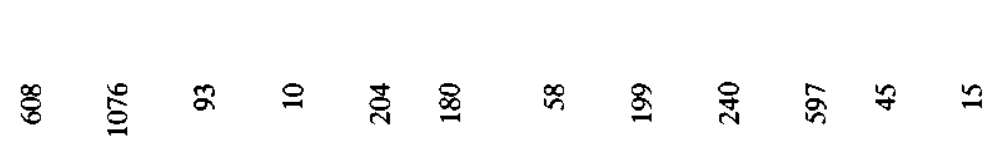

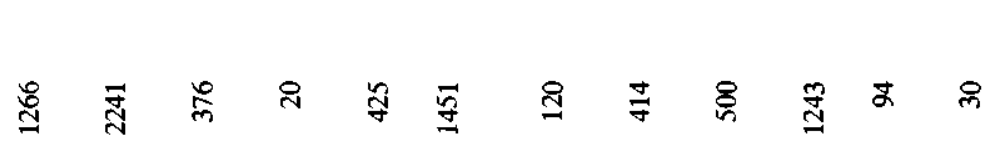

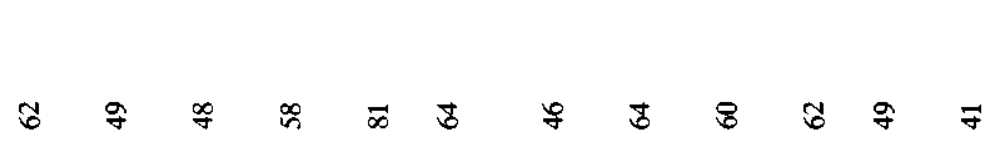

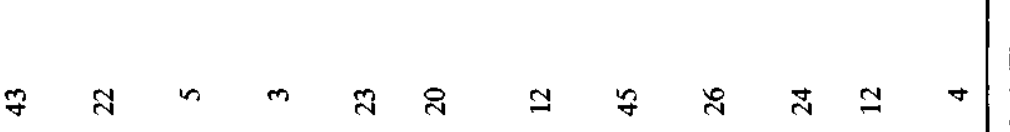

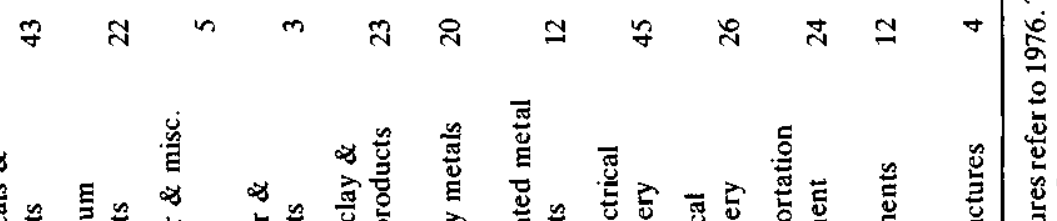

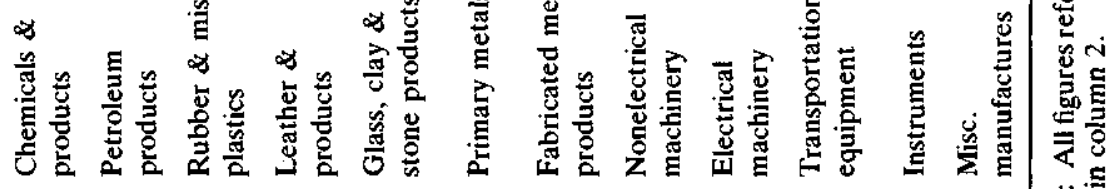

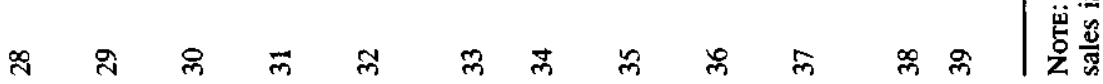




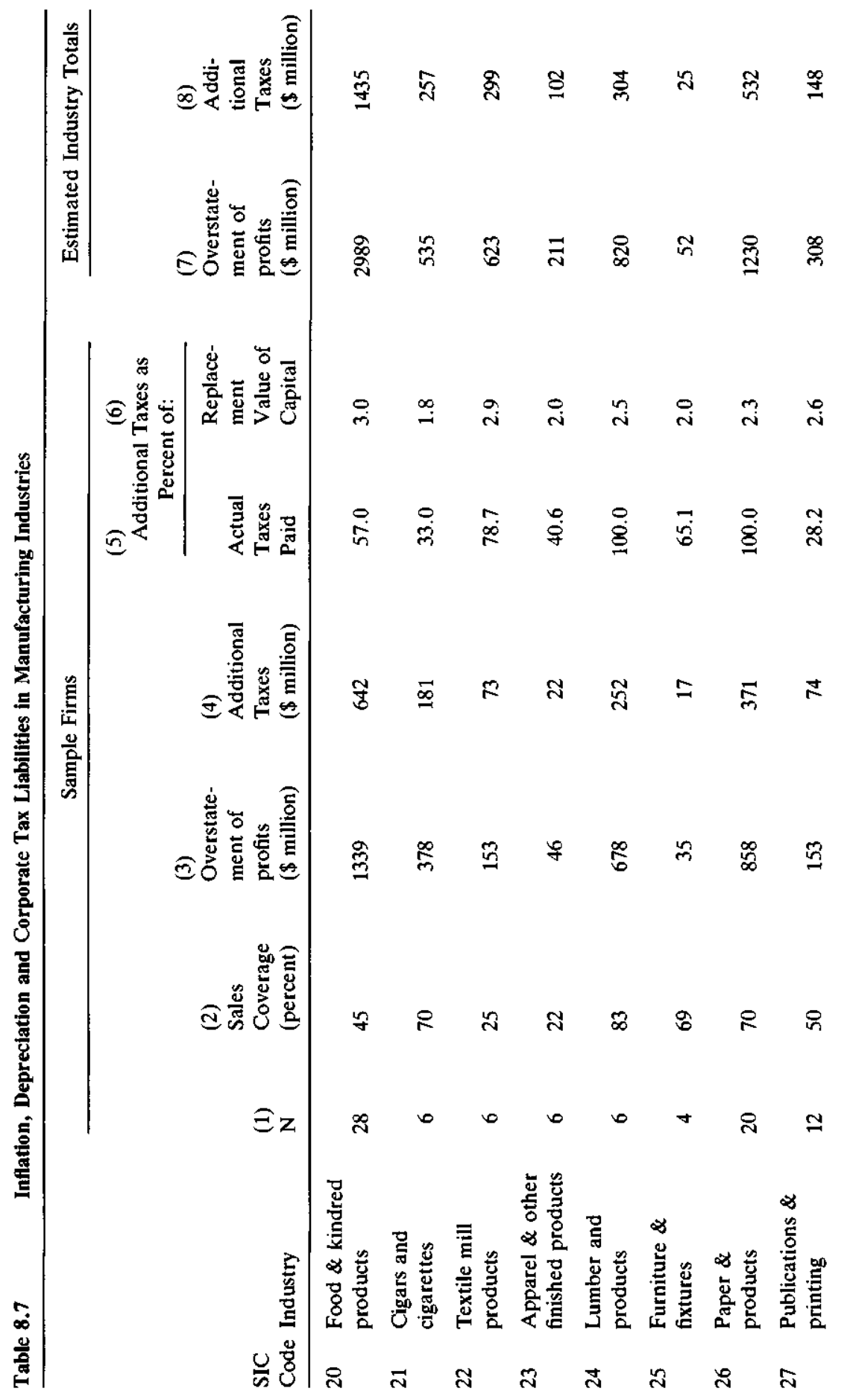




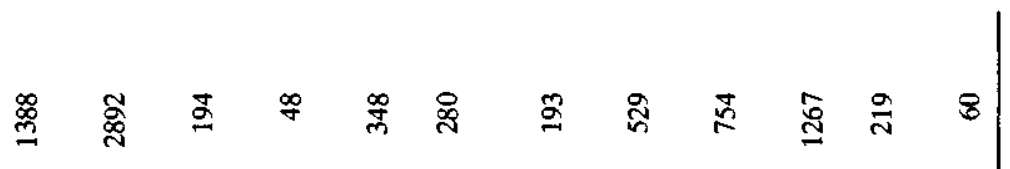

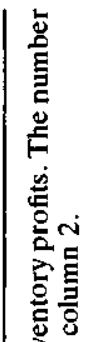

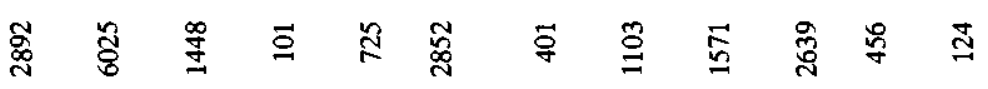

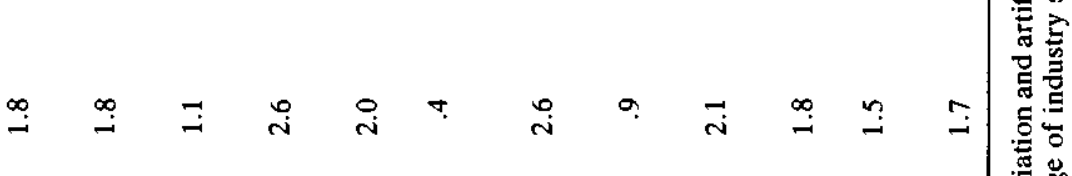

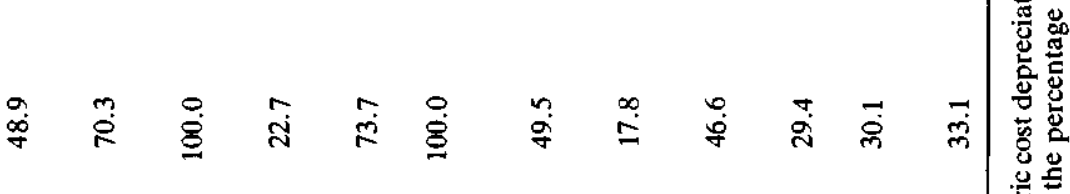

ర్ల

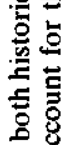

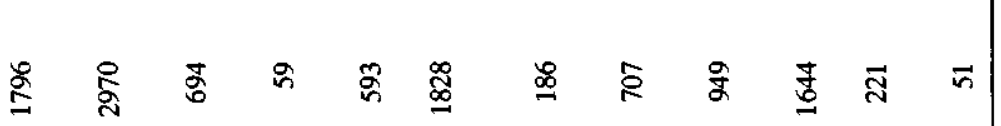

.

政

息要

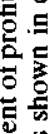

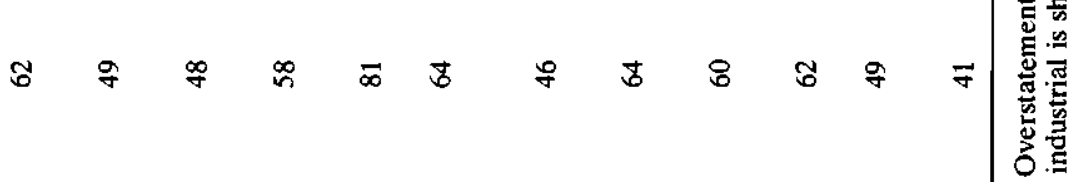

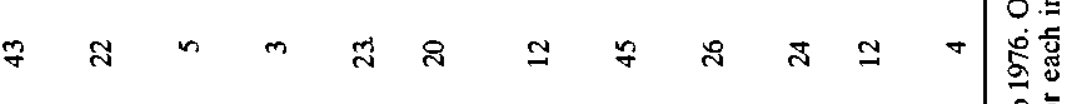

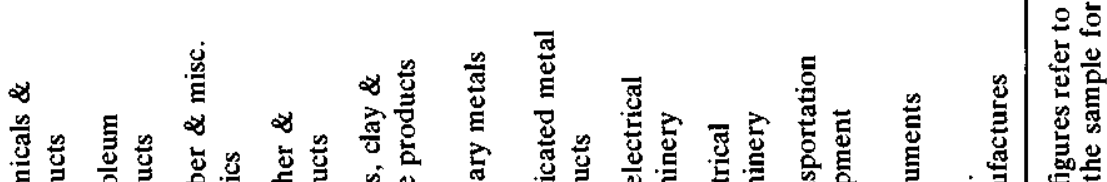

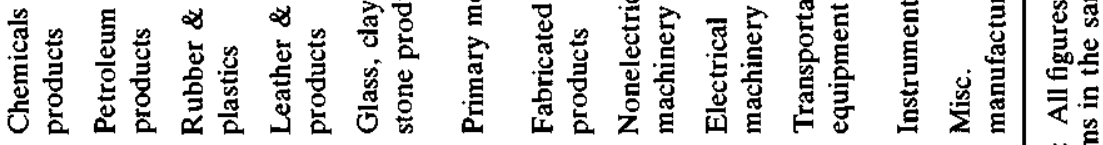

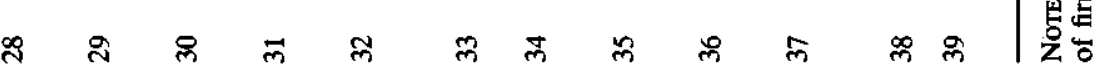


tax paid by lenders because of inflation is actually slightly greater than the taxes that corporate borrowers save by deducting higher nominal interest payments.

The overall effect of inflation with existing tax laws was to raise the real 1977 tax burden on corporate sector capital income by more than $\$ 32$ billion. This extra tax represented 69 percent of the real after-tax capital income of the nonfinancial corporate sector, including retained earnings, dividends, and the real interest receipts of the corporations' creditors. The extra tax raised the total tax burden on nonfinancial corporate capital income by more than one-half of its noninflation value, raising the total effective tax rate from 43 percent to 66 percent.

The substantial increase in the effective tax rate on capital used in the nonfinancial corporate sector can influence the performance of the economy in a number of important ways. The most obvious of these is a reduction in the rate of capital formation in response to the reduction in the real after tax return..$^{42}$

Moreover, since the tax rules that we have emphasized do not apply to residential real estate, the combination of inflation and existing tax rules will encourage a redistribution of investment away from the corporate sector and to residential construction and consumer durables. Within total corporate investment, existing tax rules will induce firms to invest more in inventories and less in equipment and structures.

The evidence on individual manufacturing industries presented in section 8.5 shows that there is substantial variation among industries in the extent to which inflation has caused greater tax burdens. In some industries, the additional tax induced by inflation accounts for less than 25 percent of actual taxes paid; in other industries, the additional tax induced by inflation is responsible for the entire actual tax payment. The additional tax varies from less than 0.5 percent of the real capital in two industries to nearly 3 percent in others. This substantial variation implies a further source of capital misallocations among individual industries within the overall manufacturing sector.

42. Although this reduction cannot be unambiguously established, in any realistic life cycle model a lower net return will reduce private saving (Summers, 1978). Some preliminary empirical evidence tends to support this view (Boskin, 1978). 


\section{Interest Rates}

and Asset Yields 
